\title{
PENILAIAN USABILITAS UNTUK SITUS E-COMMERCE (STUDI KASUS SITUS www.lazada.co.id dan www.mataharimall.com)
}

\author{
Dian Palupi Restuputri \\ Jurusan Teknik Industri, Fakultas Teknik, Universitas Muhammadiyah Malang \\ Jalan Raya Tlogomas 246 Malang
}

(Received: October 26, 2016/ Accepted: July17, 2017)

\begin{abstract}
Abstrak
Usabilitas merupakan syarat dari suatu situs E-commerce. Hal ini disebabkan apabila konsumen tidak dapat belanja dengan mudah, maka situs online tidak akan berguna. Penelitian ini bertujuan menilai dua situs e-commerce di Indonesia yaitu lazada dan mataharimall. Lazada adalah toko perbelanjaan online yang menawarkan berbagai jenis merk terkenal. Saat ini Lazada adalah situs e-commerce terbesar di Indonesia. Sedangkan mataharimall adalah ecommerce yang menawarkan berbagai jenis produk seperti pakaian, kosmetik dan kesehatan, elektronik dll. Mataharimall merupakan salah satu situs terlengkap di Indonesia. Variable usabilitas yang digunakan dalam penelitian ini adalah 9 variable usabilitas yang digunakan dari model dasar Restuputri dan Yasierli (2014). Hasil dari penelitian ini yaitu 9 variable usabilitas ini valid untuk mengukur usabilitas di situs e-commerce jenis B2C (Bussiness to Customer) yaitu lazada dan jenis O2O (Online-to-Offline dan Offline-to-Online) yaitu mataharimall. Variabel yang perlu dilakukan perbaikan baik dari situs lazada maupun matahari yaitu variabel antara lain Bantuan, Kepuasan, Kualitas Informasi, Kehandalan, Jaminan dan Kontrak Perusahaan, Keamanan dan Fasilitas dan Universality. Untuk variabel Navigasi dan Indikator Waktu tidak perlu dilakukan tindakan perbaikan karena berada di kuadran ke empat yang artinya dinilai tidak penting maupun tidak puas
\end{abstract}

Kata Kunci: e-commerce, usabilitas, user friendly

\begin{abstract}
Usability is key from e-commerce. If a customer doesn't like the site, customer simply looks for another e-commerce site to buy products from. This research assesses two largest e-commerce in Indonesia, which is lazada and mataarimall. Lazada is an online mall, offering a large selection of the world's most popular brands. Currently, Lazada Indonesia is the nation's leading business-to-consumer ecommerce site. MatahariMall is an ecommerce venture from the Lippo Group, offering one of the largest and most complete marketplaces in Indonesia. It covers fashion, health and beauty, electronics, home, groceries, books, and entertainment. Variables that used in this research based on research Restuputri and Yasierli (2014). The Results from this research is 9 variable is valid and reliable for measuring Lazada that have type e-commerce B2C (Bussiness to Customer) and Mataharimall that have type e-commerce O2O (Online to Offline and Offline to Online). There are 7 Variables that need to be improved in lazada and mataharimall, the variable are Assistance, Satisfaction, Quality of Information, Reliability, Asurance and Company Contacts, Security and Facility and Universality. For variable Navigation and Time Indicator is not necessary corrective action because it is in the fourth quadrant, which means considered not important nor dissatisfied
\end{abstract}

Keywords: e-commerce, usability, user friendly

\footnotetext{
*) Penulis Korespondensi.

email: restuputri@yahoo.com
} 


\section{Pendahuluan}

Usabilitas merupakan syarat dari suatu situs $E$ commerce. Hal ini disebabkan apabila konsumen tidak dapat belanja dengan mudah, maka situs online tidak akan berguna. Walaupun harga yang diberikan di situs lebih murah jika konsumen merasa kesulitan untuk melakukan proses pembelian, maka hal ini akan menjadi sia-sia. Tujuan konsumen selain untuk membeli yaitu juga untuk menyelesaikan pembelian secepat mungkin. Alasan "Kemudahan untuk membeli" merupakan alasan utama dari $83 \%$ responden saat melakukan transaksi online (Nielsen, 1999). Usabilitas didefinisikan sebagai sejauh mana produk dapat digunakan oleh pengguna spesifik dengan tujuan efektifitas, efisiensi dan kepuasan dalam penggunaan konteks yang spesifik (ISO 924111,1998). Dalam penelitian Hasbullah dkk (2016) tentang hubungan antara faktor sikap, norma subjektif dan usabilitas situs bagi remaja di Malaysia, ternyata faktor usabilitas dideskripsikan sebagai faktor yang paling penting untuk melakukan transaksi secara online. Usabilitas juga dianggap faktor strategis guna meningkatkan produktivitas dan performa perusahaan (Juristo dkk, 2007 ; Seffah \& Metzker, 2004)

Beberapa VC (venture capital) besar sudah menanamkan modal ke perusahan $e$-commerce yang berbasis di Indonesia, salah satunya adalah Lazada. Lazada adalah salah satu situs e-commerce ber tipe $\mathrm{B} 2 \mathrm{C}$ (business to customer) yang memiliki ranking paling tinggi di Indonesia. Menurut Alexa, Lazada menempati ranking 15 di Indonesia yang mana merupakan tertinggi untuk e-commerce. Lazada melaporkan bahwa selama online shopping day di bulan desember 2013, mereka mendapat pesanan lebih dari seribu per jam. (www.alexa.com)

MatahariMall.com merupakan online retailer pertama di Indonesia yang mengadopsi sistem belanja "O2O" (Online-to-Offline dan Offline-toOnline), yang memungkinkan para customer untuk membayar, mengambil dan mengembalikan produk di ratusan cabang Matahari Department Store di seluruh Indonesia. MatahariMall.com didukung oleh perusahaan ritel multi-format terbesar di Indonesia, yaitu Grup Lippo, yang juga mengelola Matahari Department Store dan Hypermart. Menurut Alexa, mataharimall.com menempati ranking 83 di Indonesia, padahal situs ini baru secara resmi diperkenalkan kepada publik pada bulan Sept 2015. (www.Alexa.com).

Salah satu penelitian penilaian usabilitas yang menggunakan model, adalah penelitian dari Restuputri dan Yassierli (2014). Restuputri dan Yassierli mengembangkan metode penilian usabilitas untuk e-commerce berdasarkan dari model dasar yaitu UWIS (Usability Assessment and Design of Web-Based Information System) yang dikembangkan Oztekin (2009). Dimensi yang ditambahkan oleh Restuputri dan Yassierli (2014) dari model dasar UWIS adalah kepuasan, keamanan dan fasilitas, universality, dan indikator waktu serta mengurangi dimensi controllability dan integration of communication.

Model yang dikembangkan oleh Restuputri dan Yassierli (2014) digunakan untuk meneliti $e$ commerce di bidang airlines, sedangkan Hartantyo (2013) menggunakan model UWIS untuk mengevaluasi sistem pembelian tiket online maskapai penerbangan domestik. Untuk itu perlu diadakan penelitian lebih lanjut mengenai usabilitas dari situs e-commerce dengan bidang yang berbeda sehingga dapat menganalisa apakah model yang dikembangkan oleh Restuputri dan Yassierli (2014) valid untuk segala jenis e-commerce. Penelitian ini akan menggunakan semua dimensi yang digunakan oleh Restuputri (2014) dengan bidang e-commerce yang berbeda yaitu B2C dan marketplace.

\section{Metodologi Penelitian}

Partisipan diambil dari masyarakat umum sebanyak 30 orang. Partisipan diberikan skenario yang harus dilakukan dengan cara mengoperasikan situs e-commerce yang telah ditentukan. Pelaksanaan yang diberikan dalam penelitian ini adalah withinwithin subject design, di mana setiap responden melakukan tugas yang sama pada setiap sistem pembelian barang online yang diujikan. Untuk mengurangi adanya efek pembelajaran setelah melakukan tugas pada salah satu sistem yang diujikan maka dilakukan teknik counterbalancing menggunakan metode Latin Square. Latin Square adalah teknik untuk membedakan urutan pengerjaan tugas antar responden. Tujuan lain dari penggunaan counterbalancing adalah untuk memberikan jeda waktu antar tugas agar responden dapat beristirahat. Setiap e-commerce memiliki item pertanyaan yang sama, akan tetapi untuk menghindari adanya faktor mengingat hasil dari pengisian kuesioner, item pertanyaan diacak. Setelah mengoperasikan satu situs e-commerce, diberikan jeda istirahat kepada partisipan untuk menghindari kelelahan.

\section{Uji Validitas}

Validitas instrumen diuji dengan alat analisis korelasi pearson antara item dengan total item. Jika nilai signifikansi lebih kecil dari 0.05, mengindikasikan item tersebut valid dan layak untuk tidak diikutsertakan pada tahap selanjutnya. Sebaliknya jika nilai signifikansi lebih besar dari 0.05 mengindikasikan item tersebut tidak valid. Apabila terdapat item yang tidak valid maka langsung dibuang dari kedua situs untuk pengolahan data selanjutnya.

\section{Uji Reliabilitas}

Uji reliabilitas ini untuk mengetahui keahandalan dari alat ukur yang digunakan. Digunakan koefisien Alpha Cronbanch untuk melakukan uji reliabilitas dari alat ukur. Nilai koefisien Alpha Cronbanch menggambarkan korelasi 
antara nilai observasi dengan nilai sebenarnya. Jika nilai koefisien Alpha Cronbanch di atas 0.60 mengindikasikan instrumen reliabel, sebaliknya jika nilai koefisien Alpha Cronbanch di bawah 0.60 mengindikasikan instrumen tidak reliabel.

\section{Pembentukan Faktor}

Analisa faktor merupakan pendekatan statistika yang dapat digunakan untuk menganalisis hubungan diantara banyak variabel dan menjelaskan varaiabelvariabel tersebut berdasarkan dimensi umumnya. Selain itu digunakan matriks korelasi untuk mengetahui gambaran seberapa kuat hubungan antar variabel. Matriks ini terdiri dari nilai-nilai yang menggambarkan hubungan antar variabel yang disebut dengan koefisien korelasi. Semakin kuat korelasinya maka koefisien korelasi antar variabel nilainya akan mendekati 1 (menunjukan hubungan linear sempurna). Estimasi dari korelasi faktor unik antar variabel seharusnya bernilai 0 agar asumsi analisis faktor dapat terpenuhi.

Dalam analisis faktor juga terdapat nilai Kaiser Meyer Olkin Measure of Sampling (KMO). Kaiser Meyer Olkin Measure of Sampling (KMO) adalah indek perbandingan jarak antara koefisien korelasi dengan koefisien korelasi parsialnya. Nilai KMO dianggap mencukupi jika lebih dari 0.5. Gambar 1 . merupakan tahapan tahapan penelitian yang digunakan.

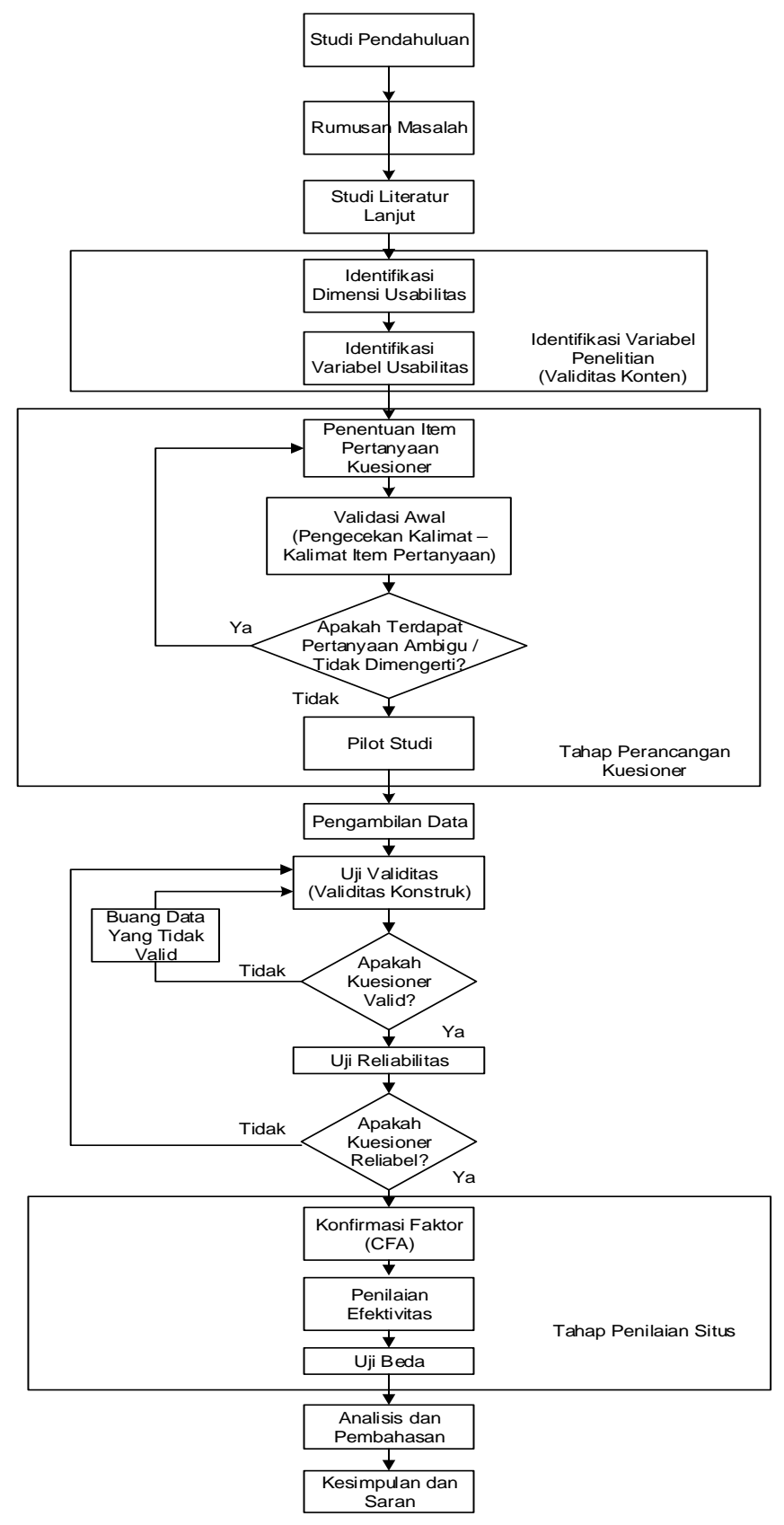

Gambar 1. Tahapan Penelitian 


\section{Pengukuran Efektivitas}

\section{Pembentukan Indeks LeVIS}

Skor Indeks yang akan digunakan untuk mengukur tingkat efektivitas situs e-commerce berdasarkan nilai LeVIS (Learner's Value Index of Satisfaction). Persamaan yang diadopsi dari LeVIS tersebut adalah indeks performansi (IP) yang berupa multiplikatif nilai (value) dan kepuasan (satisfaction). Ukuran performansi adalah satuan yang digunakan untuk mengkuantifikasikan efisiensi atau efektivitas suatu hal. Maka rumus indeks performansi (IP) adalah seperti di bawah ini :

$\mathrm{IP}=\left(\frac{1}{25}\right) \times \mathrm{N}_{0} \times \mathrm{K}_{0} \ldots \ldots \ldots . . .($ Jordan, 1998)

Dimana :

$\mathrm{N}_{0}=$ nilai

$\mathrm{K}_{0}=$ kepuasan

Skala yang digunakan untuk nilai (value) dan kepuasan (satisfaction) adalah antar 1 -5. Perhitungan nilai IP adalah multiplikasi dari nilai (value) dan kepuasan (satisfaction) yang kemudian dibagi dengan 25 yang merupakan skor maksimum yang mungkin dari skala pengukuran.

Nilai IP mempunyai nilai antara 0 dan 1 . Jika skor indeks bernilai mendekati 0 berarti tingkat efektivitas rendah, sedangkan sebaliknya jika skor indeks bernilai mendekati 1 maka tingkat efektivitas dinilai semakin tinggi.

\section{Hasil}

\section{Pengujian Validitas Instrumen Penelitian}

Pangujian Validitas instrumen menggunakan dengan alat analisis Korelasi Pearson. Jika nilai korelasi pearson (r) lebih besar dari 0.30, mengindikasikan item tersebut valid dan layak untuk tidak diikutsertakan pada tahap selanjutnya. Sebaliknya jika nilai korelasi pearson (r) lebih kecil dari 0.30 mengindikasikan item tersebut tidak valid.

Pada penelitian ini menggunakan tiga jenis data yaitu (1) data tingkat kepentingan responden terhadap situs lazada dan matahari, (2) data kepuasan responden situs lazada, dan (3) data kepuasan responden situs matahari.

Berdasarkan perhitungan validitas terlihat bahwa semua item pertanyaan pada ketiga jenis data (tingkat kepuasan responden, tingkat kepuasan responden situs lazada, dan tingkat kepuasan situs matahari) memiliki nilai korelasi $r$ yang lebih besar dari 0.30 sehingga instrumen penelitian dinyatakan valid.

\section{Pengujian Reliabilitas Instrumen Penelitian}

Sedangkan reliabilitas instrumen diuji dengan alat analisis Alpha Cronbach. Jika nilai koefisien alpha cronbach di atas 0.60 mengindikasikan instrumen reliabel, sebaliknya jika nilai koefisien alpha cronbach di bawah 0.60 mengindikasikan instrumen tidak reliabel.
Dari uji validitas, nilai alpha cronbach untuk semua variabel (Dimensi) ialah lebih besar dari 0.6, sehingga semua instrumen dalam penelitian ini dapat dikatakan reliabel (handal). Selanjutnya dapat dilakukan analisis konfirmatori (Confirmatory Factor Analysis).

\section{Analisis Faktor Konfirmatori (CFA)}

Analisis factor konfirmatori bertujuan untuk mengkonfimasi item-item pembentuk dari suatu Dimensi atau variable. Confirmatory factor analysis diukur dari nilai loading factor pada setiap indikator ke variabel laten. Nilai loading factor menunjukkan bobot dari setiap indikator sebagai pengukur dari masing-masing variabel. Indikator dengan loading factor besar menunjukkan bahwa indikator tersebut sebagai pengukur variabel yang terkuat (dominan).

Pada penelitian ini terdapat 9 variabel (dimensi). Variabel pertama sampai ketujuh dilakukan analisis CFA. Namun untuk variable kedelapan dan kesembilan tidak memerlukan CFA karena variabel hanya terdiri dari satu item. CFA dilakukan pada ketiga sub data : (1) data tingkat kepentingan responden terhadap situs lazada dan matahari, (2) data kepuasan responden situs lazada, dan (3) data kepuasan responden situs matahari.

\section{CFA pada Tingkat Kepentingan}

Dalam analisis faktor, terdapat nilai Kaiser Meyer Olkin Measure of Sampling (KMO). Kaiser Meyer Olkin Measure of Sampling (KMO) adalah indek perbandingan jarak antara koefisien korelasi dengan koefisien korelasi parsialnya. Nilai KMO dianggap mencukupi jika lebih dari 0.5. Hasil penelitian menunjukkan bahwa Kaiser Meyer Olkin Measure of Sampling untuk Analisis Faktor pada tingkat kepentingan responden pada masing-masing dimensi ialah berturut-turut sebesar $0.650 ; 0.514$; $0.601 ; 0.552$ (CFA 2); 0.581 (CFA 2); 0.500; dan 0.677 yang berarti memenuhi syarat karena bernilai di atas 0.5.

Banyaknya faktor yang terbentuk dapat dilihat dari frekuensi nilai eigen yang lebih dari 1. Dari tabel analisis, dimensi Bantuan (X1), Kualitas Informasi (X3), Jaminan dan Kontrak Perusahaan (X6), dan Keamanan dan Fasilitas (X7) memiliki frekuensi nilai eigen $>1$ hanya terdapat pada satu komponen, sehingga factor yang terbentuk hanya 1 (konfirmasi). Artinya bahwa dimensi Bantuan (X1), Kualitas Informasi (X3), Jaminan dan Kontrak Perusahaan (X6), dan Keamanan dan Fasilitas (X7) signifikan diukur oleh masing-masing item pembentuknya.

Dimensi Kepuasan (X2), Kehandalan (X4), dan Navigasi (X5) memiliki frekuensi nilai eigen > 1 sebanyak dua komponen sehingga perlu dilakukakan analisis CFA ulang dengan mengeliminasi item yang memiliki nilai loading factor terkecil yaitu X4, X14, dan X15. Hasil analisis CFA kedua diperoleh frekuensi nilai eigen $>1$ hanya pada satu komponen, sehingga dapat dikatakan bahwa Dimensi Kepuasan 
(X2) signifikan dikukur oleh item X5, X6, X6, dan $\mathrm{X} 7$, dimensi Kehandalan (X4) signifikan diukur oleh $\mathrm{X} 11, \mathrm{X} 12$, dan X13. Sedangkan dimensi Navigasi (X5) signifikan diukur hanya oleh item X16, X17, dan X18.

\section{CFA pada Tingkat Kepuasan responden Situs Lazada}

Hasil penelitian menunjukkan bahwa Kaiser Meyer Olkin Measure of Sampling untuk Analisis Faktor pada tingkat kepuasan responden Situs Lazada pada masing-masing dimensi ialah berturut-turut sebesar 0.523 ; 0.565; 0.629; 0.522; 0.501; 0.500; dan 0.541 yang berarti memenuhi syarat karena bernilai di atas 0.5 .

Banyaknya factor yang terbentuk dapat dilihat dari frekuensi nilai eigen yang lebih dari 1. Dari tabel analisis, dimensi Bantuan (X1), Kepuasan (X2), Kualitas Informasi (X3), Kehandalan (X4), Navigasi (X5), Jaminan dan Kontrak Perusahaan (X6), dan Keamanan dan Fasilitas (X7) memiliki frekuensi nilai eigen $>1$ hanya terdapat pada satu komponen, sehingga factor yang terbentuk hanya 1 (konfirmasi). Artinya bahwa dimensi Bantuan (X1), Kepuasan (X2), Kualitas Informasi (X3), Kehandalan (X4), Navigasi (X5), Jaminan dan Kontrak Perusahaan (X6), dan Keamanan dan Fasilitas (X7) signifikan diukur oleh masing-masing item pembentuknya (item X4, X14, dan X15 gugur berdasarkan hasil pada analisis CFA tingkat kepentingan responden).

\section{CFA pada Tingkat Kepuasan responden Situs Matahari}

Hasil penelitian menunjukkan bahwa Kaiser Meyer Olkin Measure of Sampling untuk Analisis Faktor pada tingkat kepuasan responden Situs Matahari pada masing-masing dimensi ialah berturutturut sebesar 0.628; 0.557; 0.534; 0.631; 0.550; 0.550 ; dan 0.534 yang berarti memenuhi syarat karena bernilai di atas 0.5 .

Banyaknya factor yang terbentuk dapat dilihat dari frekuensi nilai eigen yang lebih dari 1. Dari tabel analisis, dimensi Bantuan (X1), Kepuasan (X2), Kualitas Informasi (X3), Kehandalan (X4), Navigasi (X5), Jaminan dan Kontrak Perusahaan (X6), dan Keamanan dan Fasilitas (X7) memiliki frekuensi nilai eigen $>1$ hanya terdapat pada satu komponen, sehingga factor yang terbentuk hanya 1 (konfirmasi). Artinya bahwa dimensi Bantuan (X1), Kepuasan (X2), Kualitas Informasi (X3), Kehandalan (X4), Navigasi (X5), Jaminan dan Kontrak Perusahaan (X6), dan Keamanan dan Fasilitas (X7) signifikan diukur oleh masing-masing item pembentuknya (item $\mathrm{X} 4$, X14, dan X15 gugur berdasarkan hasil pada analisis CFA tingkat kepentingan responden).

\section{Analisis Kepentingan dan Kepuasan Berdasarkan Masing-Masing Dimensi \\ Evaluasi dilakukan dengan menggunakan 9 dimensi yang digunakan untuk mengevaluasi situs $e$ -}

commerce yaitu Lazada dan Matahari. Setelah itu dilakukan perhitungan nilai IP (Indeks Performansi) untuk masing-masing dimensi. Berikut disajikan analisis kepentingan dan kepuasan pada partisipan dalam menilai situs Lazada didasarkan pada dimensinya. Dalam Tabel 1. menunjukkan analisis kepuasan dan kepentingan situs Lazada. Sedangkan pada Tabel 2. menunjukkan analisis kepuasan dan kepentingan situs Matahari.

Tabel 1. Analisis Kepuasan dan Kepentingan Situs Lazada

\begin{tabular}{|c|c|c|c|}
\hline Dimensi & $\begin{array}{l}\text { Kepuasan } \\
\text { Lazada }\end{array}$ & Kepentingan & $\begin{array}{l}\text { Indeks } \\
\text { Performansi }\end{array}$ \\
\hline Bantuan & 3,43 & 4,20 & 0,58 \\
\hline Kepuasan & 3.56 & 4,06 & 0,58 \\
\hline $\begin{array}{l}\text { Kualitas } \\
\text { Informasi }\end{array}$ & 3,38 & 4,12 & 0,56 \\
\hline Kehandalan & 3,77 & 4,08 & 0,62 \\
\hline Navigasi & 3,32 & 3,64 & 0,48 \\
\hline $\begin{array}{l}\text { Jaminan } \\
\text { dan Kontak } \\
\text { Perusahaan }\end{array}$ & 3,50 & 4,33 & 0,61 \\
\hline $\begin{array}{l}\text { Keamanan } \\
\text { dan } \\
\text { Fasilitas }\end{array}$ & 3,54 & 4,25 & 0,60 \\
\hline Universality & 3,97 & 4,11 & 0,65 \\
\hline $\begin{array}{l}\text { Indikator } \\
\text { Waktu }\end{array}$ & 3,36 & 3,81 & 0,51 \\
\hline
\end{tabular}

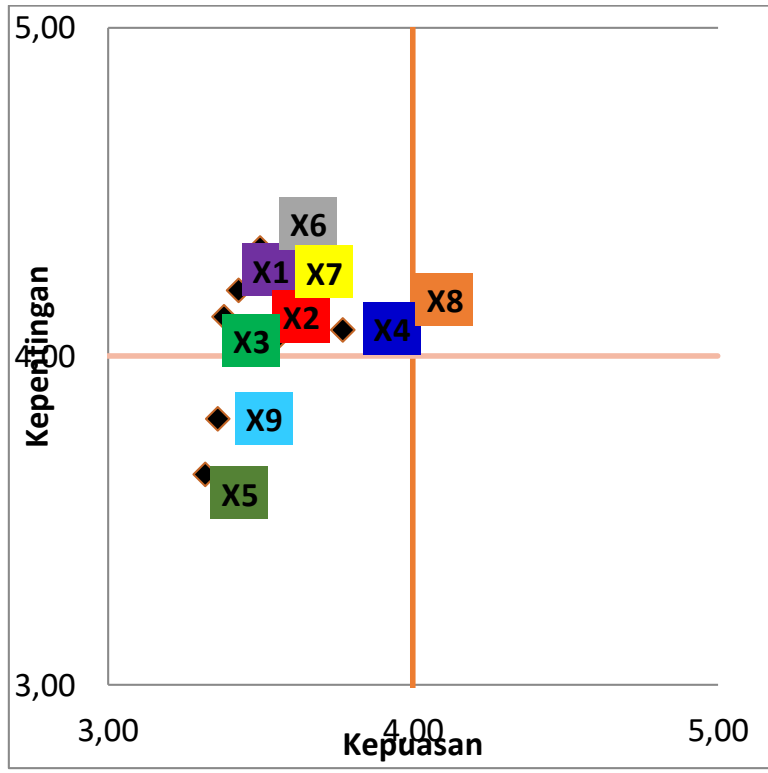

Gambar 2. Plot Grafik Efektivitas Dimensi Situs Lazada 
Berdasarkan gambar 2, sembilan dimensi terbagi pada kuadran I (perlu perbaikan) dan kuadran IV (tidak efektif). Variabel yang perlu dilakukan perbaikan yaitu enam variabel antara lain X1, X2, $\mathrm{X} 3, \mathrm{X} 4, \mathrm{X} 6, \mathrm{X} 7, \mathrm{X} 8$. Untuk sisanya tidak perlu dilakukan tindakan perbaikan karena sudah dinilai tidak penting maupun tidak puas. Variabel tersebut adalah X5, dan X9.

Tabel 2. Analisis Kepuasan dan Kepentingan Situs Matahari

\begin{tabular}{lccc}
\multicolumn{1}{c}{ Dimensi } & $\begin{array}{c}\text { Kepuasan } \\
\text { Matahari }\end{array}$ & $\begin{array}{c}\text { Kepenting } \\
\text { an }\end{array}$ & $\begin{array}{c}\text { Indeks } \\
\text { Performa } \\
\text { nsi }\end{array}$ \\
\hline Bantuan & 3,55 & 4,20 & 0,60 \\
\hline $\begin{array}{l}\text { Kepuasan } \\
\text { Kualitas }\end{array}$ & 3,60 & 4,06 & 0,59 \\
$\begin{array}{l}\text { Informasi } \\
\text { Kehandalan }\end{array}$ & 3,57 & 4,12 & 0,59 \\
\hline $\begin{array}{l}\text { Navigasi } \\
\begin{array}{l}\text { Jaminan dan } \\
\text { Kontak }\end{array}\end{array}$ & 3,35 & 4,08 & 0,62 \\
$\begin{array}{l}\text { Perusahaan } \\
\text { Keamanan } \\
\text { dan Fasilitas }\end{array}$ & 3,47 & 4,33 & 0,64 \\
$\begin{array}{l}\text { Universality } \\
\begin{array}{l}\text { Indikator } \\
\text { Waktu }\end{array}\end{array}$ & 3,61 & 4,60 & 0,61 \\
\hline
\end{tabular}

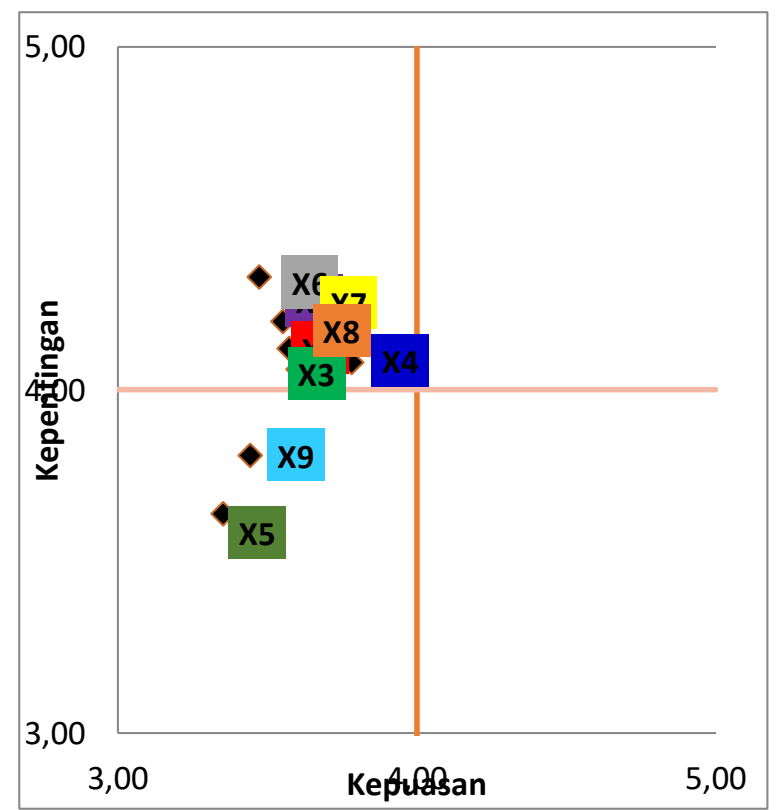

Gambar 3. Plot Grafik Nilai Efektivitas Sembilan Dimensi Situs Matahari
Berdasarkan gambar 3, sembilan dimensi terbagi pada kuadran I (perlu perbaikan) dan kuadran IV (tidak efektif). Variabel yang perlu dilakukan perbaikan yaitu enam variabel antara lain X1, X2, $\mathrm{X} 3, \mathrm{X} 4, \mathrm{X} 6, \mathrm{X} 7, \mathrm{X} 8$. Untuk sisanya tidak perlu dilakukan tindakan perbaikan karena sudah dinilai tidak penting maupun tidak puas. Variabel tersebut adalah X5, dan X9.

\section{Uji T (T-Test Analysis)}

Uji t dilakukan untuk melihat perbedaan tingkat kepuasan antara responden situs lazada dengan responden situs matahari pada setiap dimensi. Pada Tabel 3. menunjukkan hasil analisis Uji t. Berikut disajikan hasil analisis uji t pada semua dimensi :

Tabel 3. Hasil Analisis Uji t

\begin{tabular}{|c|c|c|c|c|}
\hline Dimensi & $\begin{array}{c}\text { Mean } \\
\text { Different }\end{array}$ & $\begin{array}{c}\text { t- } \\
\text { statist } \\
\text { ics }\end{array}$ & $\begin{array}{l}\text { Signifi } \\
\text { kansi }\end{array}$ & $\begin{array}{c}\text { Keteran } \\
\text { gan }\end{array}$ \\
\hline $\begin{array}{l}\text { Bantuan } \\
\text { (X1) }\end{array}$ & -0.121 & 0.945 & 0.348 & $\begin{array}{l}\text { Non } \\
\text { Signifik } \\
\text { an }\end{array}$ \\
\hline $\begin{array}{l}\text { Kepuasan } \\
\text { (X2) }\end{array}$ & -0.046 & 0.358 & 0.721 & $\begin{array}{l}\text { Non } \\
\text { Signifik } \\
\text { an }\end{array}$ \\
\hline $\begin{array}{l}\text { Kualitas } \\
\text { Informasi } \\
\text { (X3) }\end{array}$ & -0.194 & 1.560 & 0.123 & $\begin{array}{l}\text { Non } \\
\text { Signifik } \\
\text { an }\end{array}$ \\
\hline $\begin{array}{l}\text { Kehandal } \\
\text { an (X4) }\end{array}$ & -0.009 & 0.064 & 0.949 & $\begin{array}{l}\text { Non } \\
\text { Signifik } \\
\text { an }\end{array}$ \\
\hline $\begin{array}{l}\text { Navigasi } \\
\text { (X5) }\end{array}$ & -0.028 & 0.247 & 0.805 & $\begin{array}{l}\text { Non } \\
\text { Signifik } \\
\text { an }\end{array}$ \\
\hline $\begin{array}{l}\text { Jaminan } \\
\& \\
\text { Kontrak } \\
\text { Perusahaa } \\
\text { n (X6) }\end{array}$ & 0.028 & 0.172 & 0.864 & $\begin{array}{c}\text { Non } \\
\text { Signifik } \\
\text { an }\end{array}$ \\
\hline $\begin{array}{l}\text { Keamana } \\
\text { n \& } \\
\text { Fasilitas } \\
\text { (X7) }\end{array}$ & -0.065 & $\begin{array}{c}- \\
0.485\end{array}$ & 0.629 & $\begin{array}{l}\text { Non } \\
\text { Signifik } \\
\text { an }\end{array}$ \\
\hline $\begin{array}{l}\text { Universal } \\
\text { ity }(\mathrm{X} 8)\end{array}$ & 0.361 & 1.690 & 0.095 & $\begin{array}{l}\text { Non } \\
\text { Signifik } \\
\text { an }\end{array}$ \\
\hline $\begin{array}{l}\text { Indikator } \\
\text { Waktu } \\
\text { (X9) }\end{array}$ & -0.083 & $0 . \overline{413}$ & 0.681 & $\begin{array}{l}\text { Non } \\
\text { Signifik } \\
\text { an }\end{array}$ \\
\hline
\end{tabular}

Ada tidaknya perbedaan tingkat kepuasan antara responden situs lazada dengan responden situs 
matahari dilihat dari nilai signifikansi uji t. Jika nilai signifikansi uji $\mathrm{t}<0.05$ maka diperoleh kesimpulan bahwa terdapat perbedaan tingkat kepuasan responden yang signifikan antara kedua situs (lazada dan matahari). Sebaliknya jika nilai signifikansi > 0.05, maka terbukti bahwa tingkat kepuasan responden situs lazada maupun situs matahari adalah sama (tidak berbeda).

\section{Analisis}

Berdasarkan hasil analisis uji t diperoleh bahwa semua dimensi (variable) yaitu Bantuan (X1), Kepuasan (X2), Kualitas Informasi (X3), Kehandalan (X4), Navigasi (X5), Jaminan dan Kontrak Perusahaan (X6), dan Keamanan dan Fasilitas (X7) memiliki frekuensi nilai eigen $>1$ hanya terdapat pada satu komponen, sehingga faktor yang terbentuk hanya 1 (konfirmasi). Artinya bahwa dimensi Bantuan (X1), Kepuasan (X2), Kualitas Informasi (X3), Kehandalan (X4), Navigasi (X5), Jaminan dan Kontrak Perusahaan (X6), Keamanan dan Fasilitas (X7), Universality (X8), dan Indikator waktu (X9) berturut-turut memiliki nilais signifikansi 0.345 ; $0.721 ; 0.123 ; 0.949 ; 0.805 ; 0.864 ; 0.629 ; 0.629$; 0.095 ; dan 0.681 yang mana memiliki nilai signifikansi > 0.05. Hal ini menunjukkan bahwa responden mempunyai tingkat kepuasan yang sama antara situs Lazada maupun Matahari dilihat dari kesembilan dimensi (variable) penelitian. Perbandingan nilai mean (rata-rata dari kedua situs sebagai berikut) :

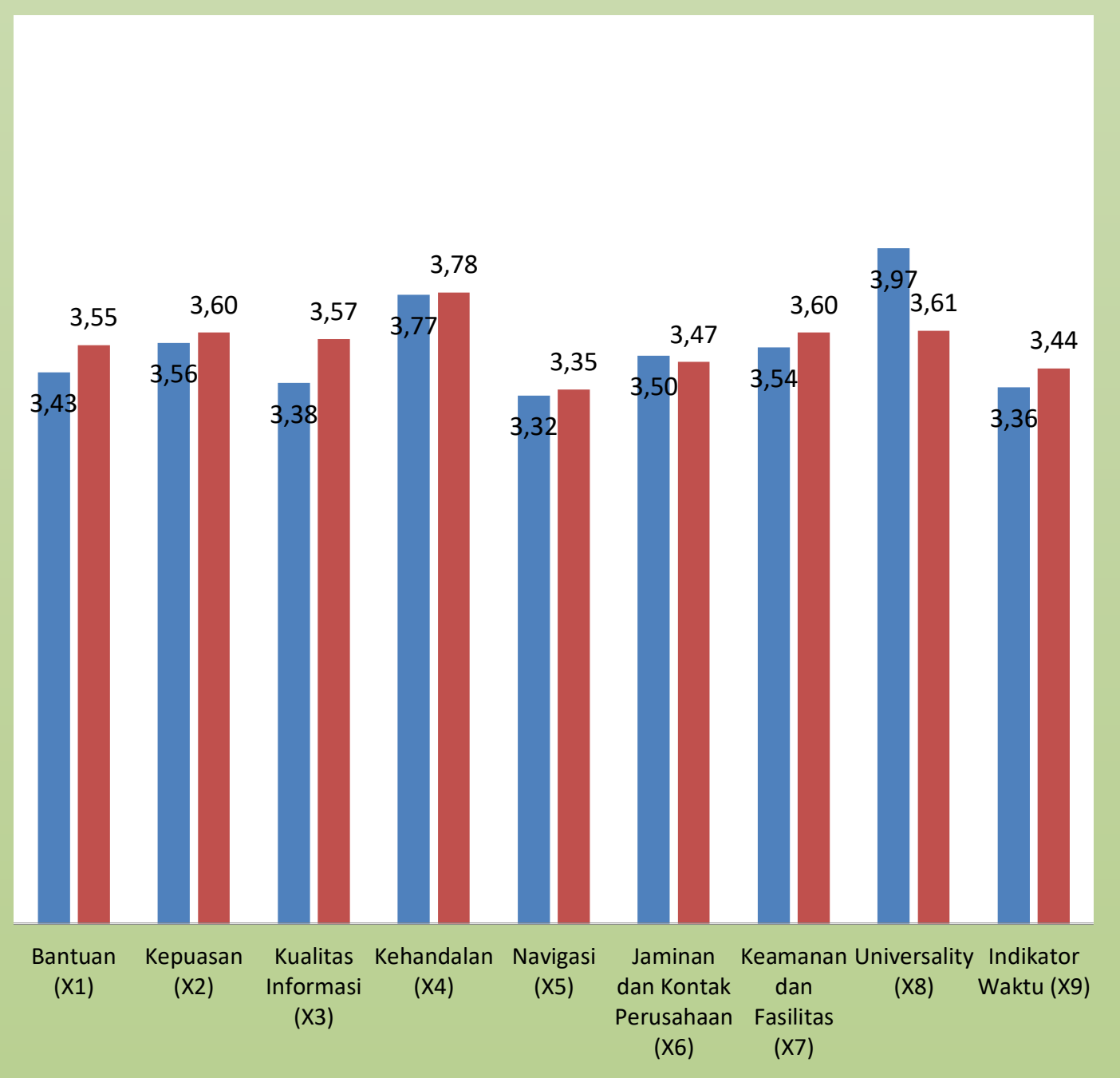

Gambar 4. Rata-rata Tingkat Kepuasan Responden Situs Lazada dan Matahari 


\section{Kesimpulan}

Dari uji validitas dan reliabilitas didapatkan hasil bahwa semua item pertanyaan pada ketiga jenis data (tingkat kepuasan responden, tingkat kepuasan responden situs lazada, dan tingkat kepuasan situs matahari) telah valid dan reliabel.

Dari hasil CFA yang mana digunakan untuk mengkonfimasi item-item pembentuk dari suatu Dimensi atau variable didapatkan hasil bahwa dimensi Bantuan (X1), Kepuasan (X2), Kualitas Informasi (X3), Kehandalan (X4), Navigasi (X5), Jaminan dan Kontrak Perusahaan (X6), dan Keamanan dan Fasilitas (X7) signifikan diukur oleh masing-masing item pembentuknya sedangkan item $\mathrm{X} 4$, X14, dan X15 gugur berdasarkan hasil pada analisis CFA tingkat kepentingan responden.

Variabel yang perlu dilakukan perbaikan baik dari situs lazada maupun matahari yaitu variabel antara lain Bantuan (X1), Kepuasan (X2), Kualitas Informasi (X3), Kehandalan (X4), Jaminan dan Kontrak Perusahaan (X6), Keamanan dan Fasilitas (X7) dan Universality (X8). Untuk variabel Navigasi (X5), dan Indikator Waktu (X9) tidak perlu dilakukan tindakan perbaikan karena berada di kuadran ke empat yang artinya dinilai tidak penting maupun tidak puas. Dari hasil nilai signifikansi uji $t$ menunjukkan bahwa responden mempunyai tingkat kepuasan yang sama antara situs Lazada maupun Matahari dilihat dari kesembilan dimensi (variable) penelitian.

\section{Daftar Pustaka}

Alexa, (2015) : Analytic For Any Website, (http://www.alexa.com/, diakses pada 29 September 2015).

Hartantyo, T. (2013) : Evaluasi Kebergunaan (Usability) Sistem Pembelian Tiket Online Maskapai Penerbangan Dometik. Tugas Akhir, Institut Teknologi Bandung.

Hasbullah, N. A, Osman, A., Abdullah, S., Salahuddin, S.N., Ramlee, N.F., Soha, H.M. (2016). The Relationship of Attitude, Subjektive Norm and Website Usability on Consumer Intention to Purchase Online : An Evidence of Malasian Youth. Procedia Economics and Finance, 35,493-502

ISO 9241-11. (1998). Guidelines for specifying and measuring usability.

Jordan, P. (1998) : An Introduction to Usability, London: Taylor \& Francis Ltd.

Juristo, N., Moreno, A. M., \& Sanchez-Segura, M. (2007). Analyzing the impact of usability on software design. The Journal of Systems and Software, 80,1506-1516.

Nielsen, J. (1994) : Usability Inspection Methods, Wiley, New York.

Oztekin, A., Nikov, A., dan Zaim, S. (2009) : UWIS: An assessment methodology for usability of web-based information systems. The Journal of Systems and Software, 82, 2037-2050

Restuputri, D.P., dan Yassierli.(2014) : The Development of Usability Assessment Tool For Airline E-Commerce Sites, In Proceedings of Joint International Conference APCHI-ERGOFUTURE-PEI-IAIFI, 52-62.

Seffah, A., \& Metzker, E. (2004). The obstacles and myths of usability and software engineering. Communications of the ACM, 47(1), 71-76. 